\title{
THE IMPACT OF PBWORKS APPLICATION ON VOCATIONAL STUDENTS' COLLABORATIVE WRITING SKILL
}

\author{
Audi Yundayani ${ }^{1 *}$, Dian Kardijan ${ }^{2}$, Rainy Dwi Apriliani ${ }^{1}$ \\ ${ }^{1}$ STKIP Kusuma Negara, Indonesia \\ ${ }^{2}$ Universitas Siliwangi, Indonesia \\ *e-mail: audi_yundayani@stkipkusumanegara.ac.id
}

\begin{abstract}
Writing skill is a productive language skills that should be mastered by vocational students. It has become a critical issue in the study of English for Specific Purposes (ESP) and a challenging one in Indonesian context in the context of English as Foreign Language learning. This paper aims to investigate the impact of PBworks media application on vocational students' collaborative writing skill. The research used the experimental approach. The respondents included 60 vocational students selected randomly and divided into two groups with 30 students in the control group and 30 students in the experimental group. The PBworks media was applied in the experimental group, while the control group received face-to-face writing class without incorporating learning media. The data were obtained by comparing student scores in the pre-test and two post-tests. The analysis of covariance (ANCOVA) was used to obtain the result. It showed that there is a statistically significant difference between using PBworks and non-PBworks media in regard to the students' writing performance $(p<.05)$. Moreover, vocational students believe in the benefit of the PBworks media application in developing collaborative writing skill despite the disadvantages.
\end{abstract}

Keywords: collaborative, English for specific purposes, PBworks, vocational students, writing skill

\section{DAMPAK APLIKASI PBWORKS \\ TERHADAP KETERAMPILAN MENULIS KOLABORATIF SISWA KEJURUAN}

\begin{abstract}
Abstrak: Keterampilan menulis merupakan suatu keterampilan produktif berbahasa yang harus dikuasai oleh siswa kejuruan. Hal ini menjadi isu penting dalam kajian bahasa Inggris untuk tujuan khusus dan selalu menjadi isu yang menantang di Indonesia dalam konteks pembelajaran bahasa Inggris sebagai bahasa asing. Penelitian ini bertujuan untuk memastikan apakah terdapat pengaruh penggunaan media $P B$ works terhadap keterampilan menulis kolaboratif siswa kejuruan. Penelitian menggunakan pendekatan eksperimen. Responden adalah 60 orang siswa kejuruan yang secara acak dipilih dan dikelompokkan ke dalam 2 grup, 30 siswa untuk kelas kontrol dan 30 siswa untuk kelas eksperimen. Media PBworks digunakan di kelas eksperimen, sementara di kelas kontrol pembelajaran menulis dilakukan hanya dengan tatap muka tanpa penggunaan media pembelajaran. Data diperoleh dengan membandingkan nilai menulis siswa (pre-test) dan di akhir perlakuan (dua kali post-test). Analisis kovarian (ANCOVA) digunakan untuk mendapatkan hasil. Temuan penelitian menunjukkan bahwa ada perbedaan yang signifikan secara statistik antara penggunaan media PBworks dan non-PBworks mengacu pada hasil menulis siswa $(p<$ $0,05)$. Selain itu, siswa kejuruan meyakini manfaat dari aplikasi media PBworks dalam mengembangkan keterampilan menulis kolaboratif, meskipun ditemukan juga kelemahannya.
\end{abstract}

Kata Kunci: kolaboratif, bahasa Inggris untuk tujuan khusus, PBworks, siswa kejuruan, keterampilan menulis

\section{INTRODUCTION}

The objective of the vocational secondary school (VSS) course in Indonesia is to prepare students to take part in the field of work. The Indonesia government stated that the spectrum of expertise in VSS must be aligned with the needs of curriculum, science, technology and development of the workforce (Peraturan Ditjen Dikdasmen RI 2018 No. 06/D.D5/KK/2018). Moreover, practical, applicative and productive English ability should be the aim of the VSS English course (García \& Litzler, 2017). The focus of the teaching process in VSS is therefore to train students "how to do" and the learning 
components should be focused on doing (Çolak \& Kaya, 2014). In order to achieve the learning goal, Case \& Gunstone (2001) believed that learning approaches have become an important concept for explaining differences in learning among students and how it affects the achievement of students. Furthermore, English learning should be relied on the ESP approach as a compulsory subject in VSS (Kardijan, 2017). Accordingly, the ESP approach is in line with those expectations because it is a language learning approach based on the need for students. This approach is intended to help students develop their communicative skills.

Writing skill as the language productive skill is required by the VSS students. It is considered as a complex language skill. There are many components that need to be integrated into performing this productive skill, namely micro skills and macro skills of writing. Writing is a process that is perceived as a cycle. In the academic field, writing is thought to be a means of knowing the knowledge of students. They are expected to be able to transform the idea they already had by constructing any information from their schemas. However, preliminary research result described that most VSS students have problems in writing skill. The lack of VSS students abilities in vocabulary mastery, words order, paragraph development is the cause of their low motivation in enjoying writing course. As the consequences, the writing skills of VSS students have not reached the target including the job requirement expectation. However, learning to write is not an easy task for many VSS students, particularly in EFL contexts where they have little exposure to real-world English use.

Collaborative writing is believed to be an approach that can be used to overcome the lack of writing skills of students. The process covers, (1) parallel writing; (2) sequential writing; (3) reciprocal or reactive writing (Ortiz \& Ferreira, 2014). Each student writes a part of the text simultaneously in the earlier step of collaborative writing, then it is shared with the next students for revision including adding the text, and all parts of the text are done by involving all members by the end. Furthermore, collaborative writing offers the potential to improve the writing performance of students not only in terms of language and content but also by facilitating the joint construction of language and knowledge including peer feedback encouraging by promoting students-centered language learning (Ramanair, Rethinasamy, \& Misieng, 2017). Collaborative writing involves students working together through their interaction in the writing process that began with the generation of ideas until the ready text is completed.

Technology has been a valuable tool in the current situation that can support human activities (Saeed \& Ghazali, 2016; Kardijan \& Yundayani, 2019). It is believed that it can facilitate human life as a supported means, including in the environment of language learning. The information and communication technology (ICT) media can be used in the EFL learning process to facilitate interaction among EFL students and native speakers, including with the English speaking environment. Furthermore, the use of ICT is in line with the characteristics of VSS students as most of them come from a millennial generation known as the digital native. They use any digital tools to support their activities. PBworks is a public web service or known as PBwiki. It offers a simple tool through a collaborative approach (Almonuf, 2018; Chu, Capio, van Aalst, \& Cheng, 2017; Ortiz \& Ferreira, 2014). As a digital platform, PBworks allows students to collaborate together by producing text that authorized students can edit quickly and easily. Students work in small groups and continue to share ideas, debate opinions, and propose arguments like revision and editing.In the implementation, teachers must begin by setting a PBworks account to be used and students registered as the user to create and edit some workspace on it. In the next step, teachers must be done training the students with details and steps of how to use the PBworks media for collaborative writing, including how to post the comments, do peers review, and others. To ensure and enhance their understanding of operating PBworks media, the orientation session needs to be given. Students can interact with each other in providing feedback or comments through this tool. It's easy to be used and enable them to share any information by learning online. The interactive and inter-creative learning environment still allows the involvement of the teacher to be created. In short, PBworks learning media supports a form of collective action and provides a good learning atmosphere for both 
teacher and peer interaction.

Many previous researchers have done studies related to wiki media domain and writing ability (Ardiasih, Emzir \& Rasyid, 2019; Almonuf, 2018; Chu et al., 2017; Esteban \& Martínez, 2014; Ortiz \& Ferreira, 2014; Ramanair et al., 2017), but as far as the researchers are aware, no one has specifically studied and linked the collaborative writing performance of PBworks media and vocational secondary students. The current research focuses on the use of PBworks media to apply collaborative writing principles in accordance with the ideals of a process-based approach that allows students to refine their writing process and produce their final work. It is important for teachers to introduce interactive technology to support the process of collaborative writing that takes into account students' and teachers' needs.This research is therefore needed to enrich the knowledge related to the application of wiki media applied in the area of vocational students in writing skills. Ultimately, the aims of this study are to find the influence of PBworks application media on the collaborative writing of vocational students and to gain a deeper understanding of the perceptions of students about PBworks media using both the advantages and disadvantages.

\section{METHODS}

\section{Respondents}

The study applies the quasi-experimental design with two groups (nonequvalent pretestposttest control group design). Its involved 60 participants to examine the impact of PBworks media. They were taken after a writing task took the homogeneous test and assigned randomly in two different groups, 30 participants in a control group and 30 participants in the experiment group.The control group participants did not give treatment and the entire process of writing learning was done through conventional method by face-to-face interaction. It was different from the group of experiment that the PBworks media treated. To mention significantly, the participants in both the experimental and control groups did their 3 writing assignments until the end of the course. The essays were dedicated to specific and academic topics such as my university, my high school, and my favorite place to go. The researchers explained that the main responsibilities of the students were supposed to post their writings on their group pages and to comment on each other's texts as well as give each other feedback. The writing test with the same topics was assigned to both the control and experiment group participants. To strengthen the findings, 4 participants were taken to be interviewed to know the advantages and disadvantages of their perceptions of PBworks media application.

\section{Instruments}

The instruments were required to collect the data. The data collection procedures covered (1) pilot testing; (2) homogeneous participant; (3) pre-test and post-test administration; (4) treatment period; (5) interviewing. Quantitative data was taken from the instruments of writing tests. The task of writing an essay of 200 words in 35 minutes was assigned to both experiment and control group. Previously, participants were asked to write an essay to homogenize their writing score based on the results. In order to examine their writing performance, the reliability of the research instruments and the homogenization of the participants were first ensured.The task of writing an essay was applied at the beginning of the course to know the early writing ability of the participants as pretest. In order to know the achievement of students in writing performance, both the control group and the experiment group were given the task of writing an essay again at the end of the course as post-test.

For each interview, the qualitative data was taken from a semi-structured interview with 4 participants with a duration of 15 to 20 minutes and the responses of the interviewees were recorded to avoid the lost data. The interview was conducted to use the perceptions of students regarding PBworks media. The researchers designed the question indicator referring to the goal to be achieved. Two language experts checked the appropriateness and accuracy of the interview items. Furthermore, two raters were involved to ensure the consistency of ratings.

\section{Procedures}

The researchers began with designing steps to collect the data included pilot testing, homogeneous of the participant, writing test administration as pre-test and post-test, 
conducting treatment sessions, and running the semi-structured interview. Previously, the reliability of the research instruments and homogeneous participants was ensured by giving academic writing test to examine the writing performance of both the control and experiment groups. After giving the pre-test, the treatment sessions were conducted in the experiment group. In order to achieve the objective of the study, the students were provided with orientation sessions in detail and steps of how to use the PBworks media for collaborative writing, including how to post the comments, do peer review, and others.

After training was completed, each class was divided into six groups of five. Following to the program, the students were asked to write an essay each week as an assignment based on the topics given and all the writings were presented on the PBworks, so that the students of each group could view them and comment on each other's writing task, modifying their own texts as well as their peers' writings. In the following session, the researchers provided feedback and correction if any on the areas that needed to be corrected. Gradually, some writing exercise was given to be discussed and edited in the researchers' monitoring. Students have been involved in the writing process namely (1) prewriting; (2) composing; (3) peer-reviewing; (4) peer-proofreading and editing; (5) publishing. The Figures 1 and 2 show the collaborative writing skills display of the PBworks media application.

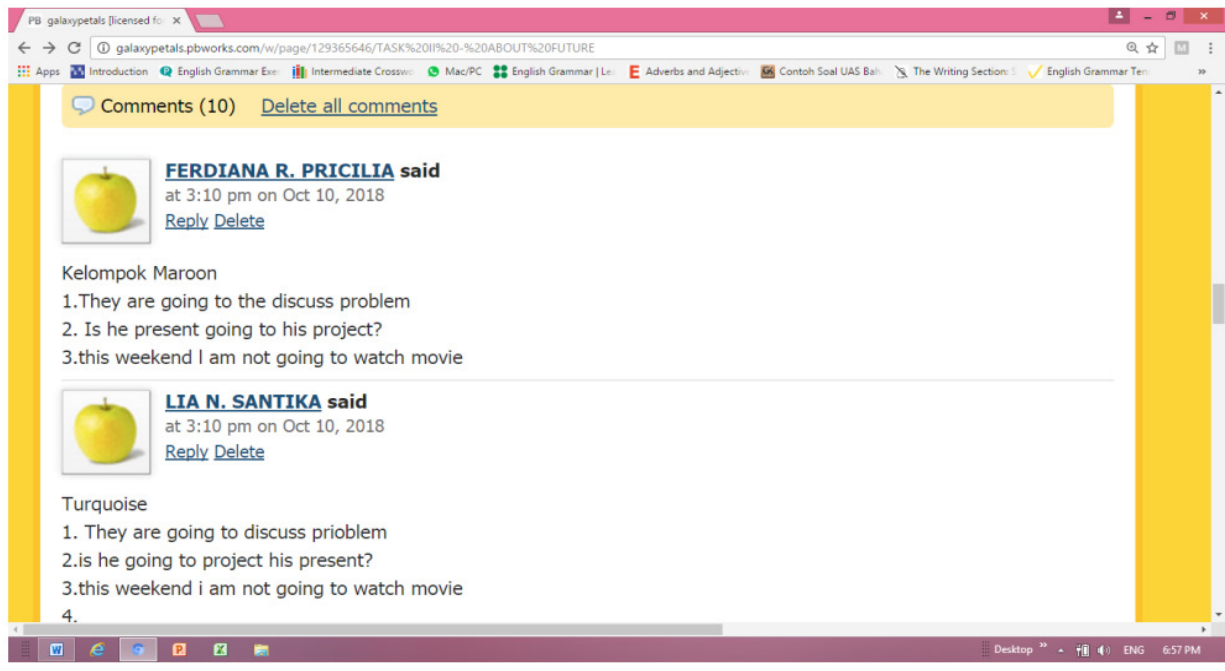

Figure 1. A sample of PBworks Media for Collaborative Writing Skill

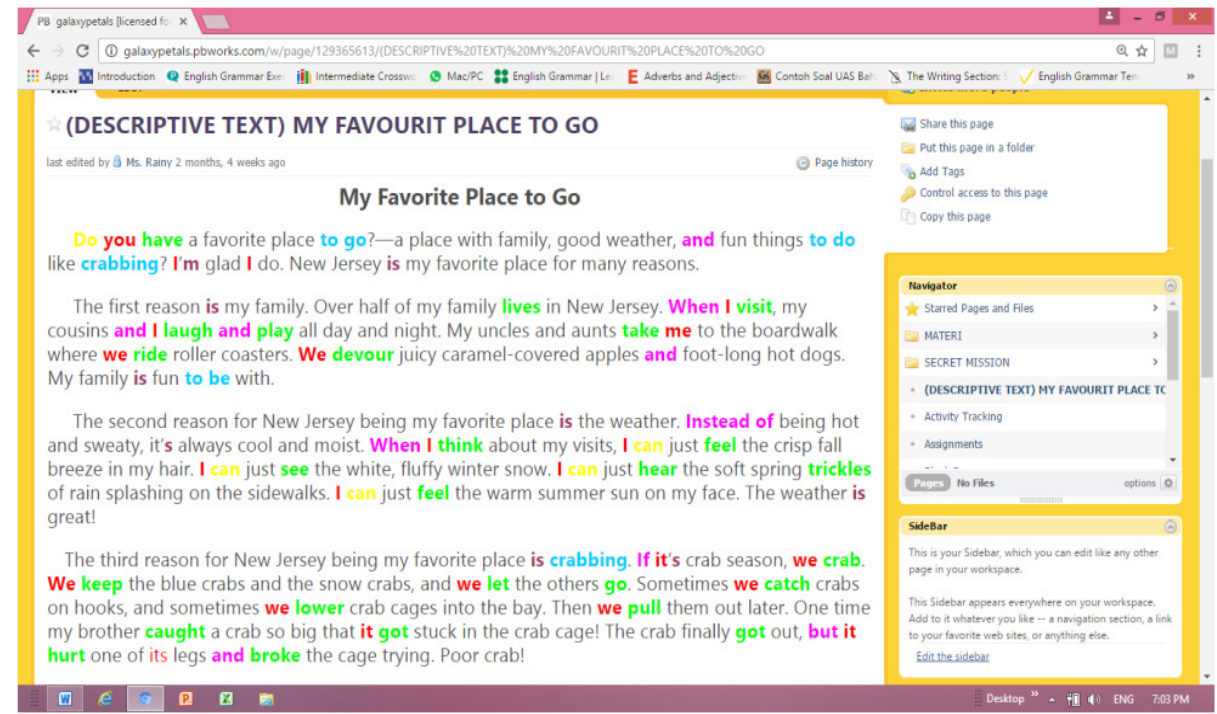

Figure 2. A Sample of Interactive Communication on PBworks Media 
In particular, the students were engaged in five stages of the writing process. The researcher encouraged the students to return to the review point's history explained by the researcher and their peers. It could be used as a reference and information for their sub sequent writing. This process continued until the students provided 3 writings as assignment needed.

Meanwhile, there was no experience of PBworks used for participants in the control group. They were taught through conventional instruction by face-to-face writing course that provided with some writing samples and models on the whiteboard and paper. They were practiced and monitored by the researchers as well as provided with explicit feedback mostly only focus on aspects of their writing, including the vocabulary, grammar, organization, content, and mechanics. Similarity, they required 3 writing assignments during the course like the practices assigned for the participants in the experimental group. In the end, the same writing test for both the control group and the experiment group administered a post-test to compare the groups' score gains and figure out whether or not their writing performance improved. Then, a semi-structured interview was conducted, whose results paved the way to provide an understanding of the perceptions of students about PBworks media used.

\section{Data Analysis}

The data were quantitatively analyzed from the experimental results and corroborated by qualitative data. The quantitative data were first gathered and analyzed. It was continued through the collection of qualitative data, including analysis. The quantitative data are taken from the pre-test and post-tests that analyzed using descriptive statistics and Analysis of Covariance (ANCOVA) utilizing the Statistical Packages for the Social Sciences (SPSS). Previously to beginning ANCOVA, the normality assumptions were examined. Since the two raters had scored in evaluating these writing, the Pearson productmoment correlation coefficient was used to measure inter-rater reliability to determine the extent of an agreement of the raters. Besides, a semi-structured interview was used to explore the perceptions of students. The result of the interview was tabulated using descriptive statistics of frequency counts.

\section{FINDINGS AND DISCUSSION Findings}

An analysis of correlation was used to test the null hypothesis. The writing scores of the participants in both groups were rated by two raters. All ratings of both groups in pretest and post-test, even the writings of the experimental group in the treatment sessions, were correlated to check inter-rater reliability. On the whole, all these correlation coefficients indicated that there was high agreement between the raters. Afterward, the average scores of the two raters were computed included in the main analysis. After ensuring inter-rater reliability, the descriptive statistics of the two groups in terms of their writing scores were computed (Tables 1 and 2). It should be noted that the experimental group also had 4 sessions of treatmentfor practicing writing through PBworks including a good orientation to PBworks used, whose descriptive statistics were also computed.

Table 1. Descriptive Statistics (Control)

\begin{tabular}{lccccccc}
\hline & & & & \multicolumn{2}{c}{ Skewness } & \multicolumn{2}{c}{ Kurtosis } \\
\cline { 5 - 8 } & & Mean & Std. Deviation & Statistic & $\begin{array}{c}\text { Std. } \\
\text { Error }\end{array}$ & Statistic & $\begin{array}{c}\text { Std. } \\
\text { Error }\end{array}$ \\
\hline Pre-test & 30 & 4.83 & 1.32 & -.38 & .62 & -.42 & .86 \\
Post-test & 30 & 5.26 & 1.86 & -.61 & .62 & -.83 & .86 \\
Valid $N$ (listwise) & 30 & & & & & & \\
\hline
\end{tabular}


Table 2. Descriptive Statistics (Experimental)

\begin{tabular}{lccccccc}
\hline & & & & \multicolumn{2}{c}{ Skewness } & \multicolumn{2}{c}{ Kurtosis } \\
\cline { 5 - 8 } & & Mean & Std. Deviation & Statistic & $\begin{array}{c}\text { Std. } \\
\text { Error }\end{array}$ & Statistic & $\begin{array}{c}\text { Std. } \\
\text { Error }\end{array}$ \\
\hline Pre-test & 30 & 4.92 & 1.32 & -.16 & .54 & -.84 & .84 \\
Session 1 & 30 & 5.12 & 1.56 & -.73 & .54 & .58 & .84 \\
Session 2 & 30 & 5.34 & 1.64 & -.124 & .54 & 1.43 & .84 \\
Session 3 & 30 & 5.87 & 1.48 & -.112 & .54 & 1.28 & .84 \\
Session 4 & 30 & 6.26 & 1.73 & -.86 & .54 & -.62 & .84 \\
Post-test & 30 & 6.74 & 1.54 & -.34 & .54 & -.36 & .84 \\
Valid $N$ (listwise) & 30 & & & & & & \\
\hline
\end{tabular}

Table 2 showed the enhancement of collaborative writing performance of students across the pre-test, treatment session, and posttest within the experimental group. In order to confirm this enhancement is significant compared with the control group, both posttest in the experimental and control group compared through the Analysis of Covariance (ANCOVA). The reason for running ANCOVA, it was not clear whether the groups were equal in terms of mean writing scores on the pre-test, so the probable pre-test differences between the groups were taken into account by employing analysis of covariate effect. Furthermore, several assumptions need to be checked initially. This is the normality assumption, based on the skewness and kurtosis ratios indicated normality, which was not beyond - 1.96. The next assumption is the homogeneity of variances that done based on the results of Levene's test in Table $3(p>.05)$.
Table 3. Levene's Test of Equality of Error Variances

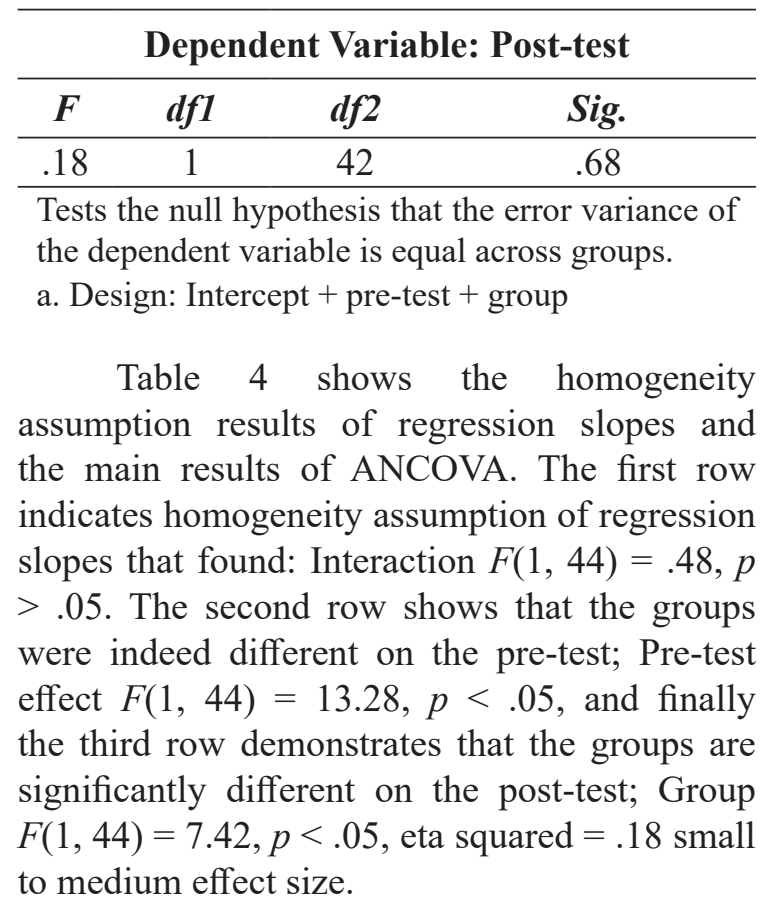

Table 4. ANCOVA Results

Dependent Variable: Post-test

\begin{tabular}{lccrrc}
\hline \multicolumn{1}{c}{ Source } & $\boldsymbol{d} \boldsymbol{f}$ & Mean Square & $\boldsymbol{F}$ & Sig. & $\begin{array}{c}\text { Partial Eta } \\
\text { Squared }\end{array}$ \\
\hline Group * pre-test (interaction) & 1 & .87 & .48 & .52 & \\
Pre-test (covariate) & 1 & 32.46 & 13.28 & .02 & .32 \\
Groups comparison & 1 & 18.34 & 7.42 & .00 & .18 \\
Error & 53 & 5.076 & & & \\
Total & 56 & & & & \\
Corrected total & 55 & & & & \\
\hline
\end{tabular}

a. $R$ Squared $=.284$ (Adjusted $R$ Squared $=.251)$ 
Through the statistical data, we can draw the conclusion that there are statistically significant differences on their collaborative writing performance between PBworks media and non-PBworks media users.

In connection with the PBworks media application on the collaborative writing performance of vocational students, all respondents acknowledged its positive impacts. Due to their enjoyable experience in joining the collaborative writing process by using the PBworks media, they performed higher motivation in writing. As a result, their writing ability improved. They were eager to learn the writing skills and it is necessary to appreciate their willingness to participate actively in the writing process. A problem faced by the respondents related only to the quality of the internet network that was not yet delivered at school to the maximum.

The transcriptions in Table 5 provided by the experimental group respondents show the responses of the students in order to gain a better understanding. Table 5 describes the good points of PBworks media application. On the other hand, the students also defined the disadvantages as shown in Figure 3.

Table 5. Transcriptions of the Students' Responses

\begin{tabular}{cll}
\hline No. Indicator & Respondent & Responds \\
\hline 1. Motivation & No. 4 & $\begin{array}{l}\text { We never had any experience using media to learn English. This } \\
\text { (PBworks media using) was our first experience and I and my } \\
\end{array}$ \\
& friends were very excited.
\end{tabular}

No. 12 I thought that this media was difficult to be used and it could not support my English writing skill, but I was wrong. This media was easy to be used and it could motivate me and my friends to be active in learning writing skill.

2. Collaboration $\quad$ No.19 I and my friend had a wonderful time learning English. We could make a writing product together and we could make any revision based on the suggestions given.

3. Recognition of No.2 This media using increased my motivation in understanding writing writing components mechanism and exploring the English grammatical pattern, and in addition, I pushed my self to improve my English vocabulary mastery.

4. Time-effectiveness No.5 I felt terrible when I have a writing assignment due to the limited time in English Class. This PBworks media can solve my burden. I could make a discussion and a collaboration with my peers including asking my teacher anytime not only in class.

5. Self confidence No.6 I have done writing an assignment on time. PBworks media has given a change to improve ability in writing.

No. 13 I was proud of my self because I can finish my writing assignment on time and I got a good score.

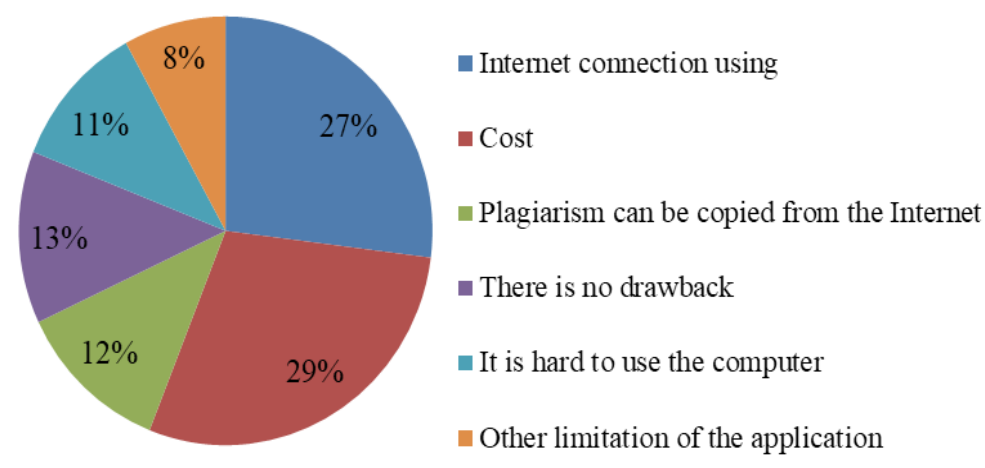

Figure 3. The Disadvantages of PBworks Media Application 


\section{Discussion}

The results of the research were derived from a quantitative and qualitative method. The ANCOVA test was used to perform a quantitative method. It was recognized that there are statistically significant differences between PBworks and non-PBworks users in collaborative writing performance. The null hypothesis was rejected and it proved that there is an influence of PBworks application media on vocational students' collaborative writing. This finding was consistent with some previous research that indicated the influence of technology media on language performance of students, including writing skills. (Almonuf, 2018; Carrió-Pastor \& Skorczynska, 2015; Ramanair et al., 2017). On the other hand, the writing performance of students can be enhanced through the media of technology. It includes PBworks in improving the writing performance of students because it provides a collaborative environment and a positive stimulus for interaction (Chu et al., 2017; Ortiz \& Ferreira, 2014; Saeed \& Ghazali, 2016; Sumtsova, Aikina, Bolsunovskaya, Phillips, Zubkova, \& Mitchell, 2018). PBworks application enables students to interact during the process of collaborative writing. They also commit to capturing the knowledge, sharing files, and managing the projects. Writing activities can be more effective in real time through PBworks and enhance the productivity of writing.

Providing any suitable teaching media that are in line with the characteristics of the students is important for the English teacher (Huynh \& Tran, 2018). The application media of PBworks has responded to the learning media requirement of students that can support them in performing language skills, including writing. It takes a cycle to write as a process approach until it produces a writing product. Any step of writing from finding an idea, making a draft, writing sentences, developing paragraphs, including revising and reviewing should be easier when the teacher and peer feedback, interaction, and collaboration have occurred since students started writing with confusion and making many mistakes.

The qualitative results identified the thinking of students about the use of PBworks media. Five elements were found that can be seen as the benefits of PBworks media coverage, (1) motivation; (2) collaboration; (3) recognition of writing components ; (4) time- efficiency ; (5) self-confidence. These findings were consistent with earlier researches (Estaji \& Salimi, 2018). Through the Pbworks media, students' motivation increased due to this media is technology-based media that is in line with students' characteristic as digital natives. They used to interact with technology in daily life (Ebrahimzadeh \& Alavi, 2017; McLaren \& Bettinson, 2015). The aspect of collaboration was found in the application PBworks. Since writing is a process, collaboration should be undertaken to facilitate the process. The studentto-student or teacher feedback reinforced each other (Chu et al., 2017; Ortiz \& Ferreira, 2014). Mastery of writing components of students has been enhanced through writing interaction and collaboration. On the other hand, students felt that in the writing process, this media provided time-efficiency. Using PBworks media can cover the limited time to complete the class assignment. They can write anywhere, as long as the internet is available (Almonuf, 2018). Ultimately, students' self-confidence increased due to their lack of writing can be solved through collaborative writing on PBworks media. Previous research indicated that the use of suitable media in learning processes had a positive effect on language performance of students (Okada, Sawaumi, \& Ito, 2017; Mumpuni \& Nurpratiwiningsih, 2018 ).

Some disadvantages were found when applying PBworks to the collaborative writing of vocational students. The biggest drawback is cost-related. It occurred because the school institution did not provide a free internet network facility to support learning activities. Students need to provide the internet network on their own as the consequences. In other hands, students' writing activity depends on the internet network quality. Technical problems have become the main constraints for ICT integration in English language teaching in Indonesia in the 21 st century (Lubis, 2018). It's still a costly thing for students due to the internet network. In addition, students realized they could take, copy and paste any source from the internet. It makes plagiarism possible for them. It is a challenge for teachers and students alike. Students should be honest in writing. By following the rule on how to quote and do the quote, they should optimize any source taken from the internet. The teacher, on the other hand, must perform his duties as a 
facilitator, partner, observer, manager, and others (Ekawati, 2017). The teacher must understand each student's progress in writing performance, including their role, contribution, and function in the process of collaborative writing. The teacher should also have a way of confirming the validity of the writing product of the students. Surprisingly, some students said the PBworks media application has no disadvantage. They felt supported through this media using. It was believed that one of the ways to promote effective English learning through the use of ICT is by constructing the environment for effective English learning. (Zhang, Zhang, \& Jin, 2018). The emergence of the ICT application offers a new technology platform, tools, and resources for college-level English classroom teaching to promote effective learning. Another struggle relates to the computer operation difficulties of students.They don't have the ability to use the computer, but they can be motivated by the teacher to support each other; teach how to use the computer. Therefore, teachers are expected to be more professional, especially in technology, by developing their skills (Safitry, Mantoro, Ayu, Mayumi, Dewanti, \& Azmeela, 2015). Thus, they can provide their knowledge of how to operate the computer, as the basic technology tool applies. It concerns the role of teachers as the main agent of change in educational practice. Additionally, students stated that some limitations occurred when using the PBworks media. They are unable to put the image on the wiki page. In addition, they can not do the editing at the same time. The teacher should notice them in order to offer a solution. Technology can have great potential in language teaching and learning, and while this potential is not recognized, technological resources can be undervalued, underused and even unused, mainly because people who decide how to use it, teachers, have beliefs that affect their class implementation (García \& Rey, 2013). Therefore, it is more important to raise the awareness of teachers about any possibilities to overcome the lack of ICT usage so that students can see any opportunities to use it.

The quantitative data generally identified the positive impact of PBworks application on the writing performance of vocational students. Moreover, the students highlight both its benefits and its disadvantages. The research findings have finally declared the good effect of the application of PBworks on the writing performance of vocational students.

\section{CONCLUSION}

The ANCOVA test revealed a statically significant difference between the students' collaborative writing performance on the post-test than the pre-test. PBworks media on students' writing course delivered positive clout compared to face-to-face interaction without any technology media support. Thus, the null hypothesis formulated was rejected.

Students mentioned both the advantages and disadvantages of PBworks application, but they realized the benefit of this media in supporting their collaborative writing skill. The teacher should overcome the disadvantages of this media by finding a good way in line with the characteristics and learning condition of the students.

\section{ACKNOWLEDGMENTS}

We would like to thank anyone who provided insight and expertise that greatly assisted the research. We would also like to express our gratitude to our respondents for sharing their pearls of wisdom with us during the course of this research.

\section{REFERENCES}

Almonuf, H. (2018). Student collaboration in hybrid classrooms using PBWorks: A study of university students in Najran, Saudi Arabia. International Journal of Information and Education Technology, 8(8), 574-581. https://doi.org/10.18178/ ijiet.2018.8.8.1102.

Ardiasih, L. S., Emzir, E., \& Rasyid, Y. (2019). Online collaborative writing technique using Wiki: How effective is it to enhance learners' essay writing? The Journal of Asia TEFL, 16(2), 531-546. https://doi. org/10.18823/asiatefl.2019.16.2.6.531.

Case, J., \& Gunstone, R. (2001, 16-18 July). "No time to think"-Interactions between students' perceptions of time and approaches to learning. Paper presented at Higher Education Close Up Conference, Lancester University, United Kingdom. http://www.leeds.ac.uk/educol/ documents/00001747.htm. 
Chu, S. K. W., Capio, C. M., van Aalst, J. C. W., \& Cheng, E. W. L. (2017). Evaluating the use of a social media tool for collaborative group writing of secondary school students in Hong Kong. Computers \& Education, 110, 170-180. https://doi.org/10.1016/j. compedu.2017.03.006.

Çolak,E.,\&Kaya,D.(2014).Learning approaches of vocational high school students: Grade level and school type influences. Procedia - Social and Behavioral Sciences, 116, 1556-1561. https://doi.org/10.1016/j. sbspro.2014.01.434.

Carrió-Pastor, M. L., \& Skorczynska, H. (2015). Collaborative learning and communication technologies in teaching business English. Procedia - Social and Behavioral Sciences, 178, 32-37. https:// doi.org/10.1016/j.sbspro.2015.03.142.

Ebrahimzadeh, M., \& Alavi, S. (2017). Digital video games: E-learning enjoyment as a predictor of vocabulary learning. Electronic Journal of Foreign Language Teaching, 14(2), 145-158. http://e-flt.nus. edu.sg/.

Ekawati, Y. N. (2017). English teachers problems in applying the 2013 curriculum. English Review: Journal of English Education, 6(1), 41-48. https://doi.org/10.25134/ erjee.v6i1.769.

Estaji, M., \& Salimi, H. (2018). The application of Wiki-mediated collaborative writing as a pedagogical tool to promote ESP learners' writing performance. The Asian ESP Journal, 14(1), 112-141. https:// www.asian-esp-journal.com/volume-14issue-1-june-2018/.

García, L. J., \& Litzler, M. F. (2017). English for business: Student responses to language learning through social networking tools. ESP Today, 5(1), 91-107. https://doi. org/10.18485/esptoday.2017.5.1.5.

García, C. M., \& Rey, L. (2013). Teachers' beliefs and the integration of technology in the EFL class. HOW Journal, 20(1), 5172. https://www.howjournalcolombia.org/ index.php/how/article/view/23.
Huynh, T., \& Tran, V. M. Y. (2018). Using intensive technology in teaching English for environmental engineering: A case study at Danang University of Science and Technology, The University of Danang, Vietnam. The Asian ESP Journal, 14(4), 93-111. https://www.asian-esp-journal. com/volume-14-issue-4-september-2018/.

Kardijan, D. (2017). The gap between learning needs and its implementation in English for hospitality specific purposes program. English Review: Journal of English Education, 6(1), 125-126. https://doi. org/10.25134/erjee.v6i1.779.

Kardijan, D., \& Yundayani, A. (2019). The challenges of pedagogy and the application of ICT in applying English for academic purposes course: Teachers' insights. International Journal of Innovation, Creativity and Change, 9(1), 197-213. https://www.ijicc.net/images/ vol9iss1/9118_Kardijan_2019_E_R.pdf.

Lubis, A. H. (2018). ICT integration in $21^{\text {st }}$ century Indonesian English language teaching: Myths and realities. Cakrawala Pendidikan, 37(1), 11-21. https://doi. org/10.21831/cp.v37i1.16738.

McLaren, A. E., \& Bettinson, M. (2015). Impact of e-technologies on Chinese literacy programs for college second language learners. Electronic Journal of Foreign Language Teaching, 12(1), 101114. https://e-flt.nus.edu.sg/v12n12015/ mclaren.pdf.

Mumpuni, A., \& Nurpratiwiningsih, L. (2018). The development of a web-based learning to improve of a creative writing ability of PGSD students. Cakrawala Pendidikan, 37(2), 321-332. https://doi.org/10.21831/ cp.v37i2.20009.

Okada, Y., Sawaumi, T., \& Ito, T. (2017). Effects of observing model video presentations on Japanese EFL learners ' oral performance. Electronic Journal of Foreign Language Teaching, 14(2), 129-144. https://e-flt. nus.edu.sg/.

Ortiz, N. M., \& Ferreira, C. A. (2014). Proposing 
a wiki-based technique for collaborative essay writing. PROFILE Issues in Teachers' Professional Development, 16(2), 185-198. https://doi.org/10.15446/ profile.v16n2.38877.

Peraturan Ditjen Dikdasmen RI 2018 No. 06/D. D5/KK/2018. Spektrum keahlian sekolah menengah kejuruan (SMK)/madrasah aliyah kejuruan (MAK). [The spectrum of vocational secondary education expertise].

Ramanair, J., Rethinasamy, S., \& Misieng, J. (2017). Collaborative writing using Wiki: Tertiary students' perspectives. Electronic Journal of Foreign Language Teaching, 14(1), 84-101. https://e-flt.nus.edu.sg/ v14n12017/ramanair.pdf.

Saeed, M. A., \& Ghazali, K. (2016). Modeling peer revision among EFL learners in an online learning community. Electronic Journal of Foreign Language Teaching, 13(2), 275-292. https://e-flt.nus.edu.sg/ v13n22016/saeed.pdf.
Safitry, T. S., Mantoro, T., Ayu, M. A., Mayumi, I., Dewanti, R., \& Azmeela, S. (2015). Teachers' perspectives and practices in applying technology to enhance learning in the classroom. International Journal of Emerging Technologies in Learning (iJET), 10(3), 10-14. https://doi. org/10.3991/ijet.v10i3.4356.

Sumtsova, O. V., Aikina, T. Y., Bolsunovskaya, L. M., Phillips, C., Zubkova, O. M., \& Mitchell, P. J. (2018). Collaborative learning at Engineering Universities: Benefits and challenges. International Journal of Emerging Technologies in Learning (iJET), 13(01), 160-177. https:// doi.org/10.3991/ijet.v13i01.7811.

Zhang, E., Zhang, W., \& Jin, C. (2018). SPOCbased flipped classroom of college English: Construction of an effective learning model. International Journal of Emerging Technologies in Learning (iJET), 13(01), 37-45. https://doi. org/10.3991/ijet.v13i01.7513. 